\title{
On Cosmopolitan Humility and the Arrogance of States
}

\author{
Luis Cabrera ${ }^{1}$ \\ Griffith University \\ Griffith Asia Institute / School of Government and International Relations \\ Nathan, Queensland, Australia \\ 1.cabrera@griffith.edu.au
}

\begin{abstract}
Article was published as: Luis Cabrera. 2018. "On Cosmopolitan Humility and the Arrogance of States," Critical Review of International Social and Political Philosophy. Early online: doi:10.1080/13698230.2018.1497249
\end{abstract}

\begin{abstract}
One of the potentially most significant recent objections to a cosmopolitan moral approach charges an essential arrogance: cosmopolitanism disdains particularist moral insights even while - in what is said to be its most coherent form -- it seeks to bind all persons within global political institutions. It is argued here that adopting a form of institutional cosmopolitanism actually helps to meet this sort of objection. An appropriately configured such approach will have a conception of equal global citizenship at its core. This will seek to place individuals in relations of political humility, understood not as plain deference to competing moral claims but as concrete recognition of the equal moral status of others. It will seek to progressively empower as actual citizen equals those whose interests are often 'arrogantly' neglected in the current system, and to multiply mechanisms of input and challenge for them over time.
\end{abstract}

\section{Introduction}

Some of the most persistent criticisms of a cosmopolitan moral approach coalesce around claims of arrogance. Cosmopolitanism, which posits firm duties across national boundaries and grants ultimate moral significance to individuals rather than states or nations, is said to improperly reject the standing of those offering moral claims from particularist, non-universal moral views (Yack 1995; 2012; see Scheffler 1999; Nussbaum 2003; 2008). Or, it is said to embody a form of moral parochialism disguised as universalism, arrogant in implicitly

\footnotetext{
${ }^{1}$ I thank for their helpful comments Richard Shapcott, Brooke Ackerly, Haig Patapan, Terry Macdonald, Robyn Eckersley and Jamie Mayerfeld, seminar audiences at the Universities of Melbourne and Queensland, Griffith and Vanderbilt universities, and audiences at the 2016 Australian Political Theory and Philosophy Conference in Melbourne, and the 2017 Australian Political Studies Association meeting in Melbourne. I also thank the anonymous reviewers for this journal for their detailed and thoughtful feedback, and the editors for their guidance in revision. Any mistakes remaining are my own.
} 
presuming a subordinate status for those adhering to non-Western moral views (Pinsky 1996; Malcomson 1998; Pagden 2000; Audard 2013; Jeffers 2013; Helliwell and Hindess 2015). A potentially significant further claim has been offered by Bernard Yack, that both forms of cosmopolitan arrogance are reinforced by the global institutional implications of the approach (2012, Ch.11). That is, Yack, with some other critics (Miller 2002, 976; Kamminga 2006; Scheuerman 2014), and numerous cosmopolitan theorists (Pogge 1992; Held 1995; Caney 2005, Ch.5; 2006; Cabrera 2010, Chs. 2-3; Ypi 2013; Lu 2018), holds that a theoretically consistent cosmopolitanism will prescribe an integrated framework of global political institutions to back its global moral aims. Yack argues that those theorists who seek to realize 'cosmopolitan humility' in rejecting such a framework and/or seeking to incorporate non-universal moral insights, fall into incoherence. A consistent cosmopolitanism is firmly institutionalist, and it is by nature arrogant toward those adhering to particularist views (2012, 253ff; see Yack 1995).

It is argued here that, instead of reinforcing such arrogance objections, the adoption of an appropriately configured institutional cosmopolitan approach will go some distance toward answering them. Such an approach will give strong emphasis to the development of elements of citizenship within progressively more cosmopolitan political institutions regionally and globally. In the near term, it will seek to promote the recognition of equal moral standing, reciprocity and accountability across borders. In the longer term, it will seek to realize more concrete citizen standing beyond the state, and to establish mechanisms of input, participation and formal challenge to individuals within states. Such an institutional cosmopolitanism, it is argued, will be structurally oriented to political humility rather than arrogance. That collective virtue is presented here, with reference to extensive recent literatures in philosophy and psychology, not as plain deference to existing authority structures or competing moral claims. Instead, it entails an acknowledgment of the equal 
standing of others as claims makers, and an openness to input and challenge from them. By contrast, it is firm claims for state sovereignty which are more clearly oriented to political arrogance. These entail a presumed collective right to act egocentrically, to reject outsiders' standing to offer input, to challenge, or to exercise oversight, including global institutional actors responding to appeals from vulnerable domestic groups.

The article is structured as follows: the next section offers detail on cosmopolitanism and its main variants in political theory. The following one discusses some recent psychological and philosophical accounts of humility, arrogance and related political virtues and vices. Then the cosmopolitan arrogance critiques are detailed, as is the case for an instrumentally oriented approach to 'institutional global citizenship.' Adopting such an approach, it is shown, considerably strengthens responses to both types of cosmopolitan arrogance objections, besides providing institutional resources for challenging forms of political arrogance within a sovereign states system.

\section{Variants of Cosmopolitanism}

Cosmopolitanism ascribes ultimate moral significance to individuals rather than collectives. This moral significance is ascribed to all individuals equally, and they are to treat all others as having equal moral significance, regardless of their group or state memberships Pogge 1992, 48-49; Caney 2000, 525-28; 2005, 3-4; Brock 2009, 12; Shapcott 2010, Ch.2; Arneson 2016). It is distinct in these tenets from, for example, approaches which ascribe primary rights and duties to states in an international society of states (see Beitz 1999a, 181-91; Caney 2005, 1013, 265ff); and from statist or associative approaches, which give strong emphasis to existing relations of reciprocity or coercion between compatriots to limit any principles of global justice (Risse 2012, 25ff; Blake 2013, Ch.4). 
The variants of cosmopolitanism most salient here include moral, institutional, and individual. Moral cosmopolitanism is primarily concerned with assessing the justice of current global institutions and practices according to cosmopolitan principles. Individual cosmopolitanism seeks to provide principles for individual actions consistent with cosmopolitan moral principles, including in relation to emerging global political institutions (Beitz 1999b, 519; Cabrera 2010, Ch.1). Institutional cosmopolitanism advocates the development of a relatively strong and integrated framework of global political institutions. These would be capable of "overcoming problems created by a state-centric world," and achieving cosmopolitan moral aims for the global fulfillment of core individual rights, needs, capabilities, etc. (Jones 2010, 116; see Pogge 1992, 61-69; Caney 2005, 4-5; Cabrera ed., 2018. $)^{2}$

Further distinctions can be made according to the presumed demandingness and scope of cosmopolitan duties. In a recent article in this journal, Richard Arneson (2016) makes a useful comparison between 'extreme' and 'very extreme' versions (see also Miller 2002). An 'extreme' cosmopolitanism, which might more aptly be called a strong version, is one which denies that membership in large, impersonal social groups such as nations or states has noninstrumental moral significance in determining duties to others. A 'very extreme' cosmopolitanism extends the claim to duties toward family members and friends. These also would have only instrumental moral significance, as a potential means of furthering cosmopolitan moral aims globally (Arneson 2016, 557). Separately, moderate or 'rooted' cosmopolitans affirm some global moral aims but seek also to give significant weight to particularist, communal attachments within states. For example, Kwame Anthony Appiah advocates a middle path between "the nationalist who abandons all foreigners ... [and] the

\footnotetext{
${ }^{2}$ Ronzoni $(2013,158)$ makes an insightful additional distinction, highlighting a variant of 'political cosmopolitanism' focused on trans-state collective action by workers, critics of economic globalization, and others.
} 
hard-core cosmopolitan who regards her friends and fellow citizens with icy impartiality" (Appiah 2006, xiv-xv; see Erskine 2008; Kymlicka and Walker, eds., 2012). Others argue for some suprastate institutions to achieve aims consistent with a cosmopolitan approach, but they would limit global institutional development for reasons of global diversity (Habermas 2008, Ch. 11).

Yack, per above, argues that both rooted cosmopolitans and those seeking more limited global institutional development, in trying to incorporate humility simply fall into theoretical incoherence. The next section offers details on humility and arrogance, as presented in recent philosophical and psychological treatments. This will provide context for the specific arrogance claims to be considered against cosmopolitanism, and the argument that an appropriately configured cosmopolitanism is oriented to political humility.

\section{Humility and Arrogance}

Both humility and arrogance are presented in the recent literature as related to interpersonal standing. In broadest terms, the humble person appropriately acknowledges the standing of others to make claims and be treated with respect, while the arrogant person inappropriately rejects others' standing, and input or challenges they offer. We can note first that a series of influential psychological studies have investigated humility in the context of 'honestyhumility.' This is a personality trait correlated in studies across numerous languages to such adjectives as "sincere, honest, faithful/loyal, modest/unassuming, fair-minded; versus sly, deceitful, greedy, pretentious, hypocritical, boastful, pompous" (Ashton and Lee 2008, 1953; see Exline and Geyer 2004). High scores on honesty-humility have been correlated to significant pro-social behaviors, while low scores are correlated to such problems as workplace delinquency, general lawbreaking and tendencies to engage in sexual harassment (Ashton and Lee 2008, 1956-58). 
June Tangney contrasts humility with modesty, presenting humility as more centrally other-regarding, and entailing "an appreciation of the variety of ways in which others can be worthy” $(2005,413)$. Similarly, Chancellor and Lyubomirsky give explicit emphasis to egalitarian beliefs, where humility involves "seeing others as having the same intrinsic value and importance as oneself" $(2013,827)$. Rowatt and colleagues characterize humility as an attitude of openness to others and their ideas, as well as "respectfulness, willingness to admit imperfections, and a lack of self-focus or self-serving biases" (Rowatt et al., 2006, p.196; see also Meagher et al., 2015, 36; and see Davis, Worthington, and Hook 2010).

Humility is often situated directly opposite arrogance, which again entails in part a rejection of others' standing to offer input or challenges (Rowatt et al. 2006, 199; see Gregg and Mahadevan 2014; Meagher et. al 2015, 38). Samuelson and colleagues $(2014,8)$ place intellectual humility between extremes of intellectual arrogance and intellectual diffidence, where one claims to know more and less than one does respectively. More recently, a team of psychologists and philosophers found that intellectual humility correlates negatively with a range of traits which are associated with intellectual arrogance, including dogmatism, closedmindedness and excessive pride (Haggard et al. 2018).

In the philosophical literature, many have similarly focused on an attitude of openness to input from others, including when they offer challenging claims. In James Spiegel's nuanced account, for example, intellectual humility is rooted in the understanding that all persons face limits in what they can know. Of the humble person, Spiegel says: "As she becomes more aware of her epistemic fallibility, she becomes more willing to consider alternative perspectives on various issues, including those about which she feels most secure in her current convictions. ... A recalcitrance, imperviousness, or lack of interest in evidence that potentially contradicts or calls into question her view on an issue is inconsistent with recognition of her general fallibility and thus indicates the vice of closed-mindedness (as well 
as the meta-vice of intellectual arrogance)" (2012, 35; see also Hurka 2001, 110; Sinha 2012, 261).

Arrogant persons may be overbearing and openly disdain input, structuring their interpersonal relationships hierarchically (Tiberius and Walker 1998, 382). Or, they may be aloof, avoiding input or challenge while presuming that their own judgments must be correct, or that their judgements simply are not subject to challenge (Tanesini 2016; see also Roberts and Wood 2007, Ch.9). In the latter case, for example, Tanesini cites the example of an umpire at a sporting event who rejects all challenges to a clearly incorrect play call. The umpire's claim is that "a player is out because he (the umpire) says that he is out. ... he might not take his call to be a pure exercise of power. Instead he may be pointing out that he is not accountable to anyone else for the correctness of the call. He may do so without wishing to claim infallibility about the relevant facts; he is simply drawing attention to the executive function of his words" (Tanesini 2016, 84-85). In other words, the umpire and only the umpire is authorized to make the call under the circumstances, however questionable it may have actually been. I return to this scenario below.

At root, then, humility and arrogance are concerned with standing. Humility entails in part a recognition of the standing of others to offer input, claims and challenges. Arrogance entails the wrongful rejection of such standing. This rejection may be based in dubious presumptions that others are

a) not qualified to give input or challenge, or that they are

b) not authorized, as in the umpire case.

In the context of political humility and arrogance, similar collective orientations and presumptions of standing are highlighted. Essential here is Mark Button's treatment of political vices and virtues, understood as orientations and patterns of collective action which can either weaken or strengthen the reciprocal conditions of politics, especially in a 
democracy. Political vices typically involve one group's efforts to exempt itself from democratic norms, "above all, the principles of equal moral respect and equal liberty" (Button 2016, 18). For Button, the development and promotion of an ethos of political humility is indispensable to domestic democracy under modern conditions of pluralism $(2005,851$; see also Aikin and Clanton 2010; Scott 2014). More broadly here, the establishment of equal citizenship and democratic procedures can be seen as structurally oriented to political humility, representing formal, institutionally-backed affirmation of such equal standing, on which more below.

Humility and arrogance in the political frame can be usefully contrasted to what Button calls the political vice of recalcitrance: "the settled indifference to the morally valid claims of others" $(2016,87)$. Recalcitrance also entails a refusal to consider input, but not because of the other's perceived standing to give it. The recalcitrant may in fact give others an extended opportunity to make claims as political equals, but ultimately they 'believe what they believe' and will not be swayed by new evidence or logic. By contrast, arrogance entails a collective, typically institutionally backed rejection of others' standing to even give such input or challenge, and often of any obligations to justify that rejection. The next section considers specific arrogance claims against cosmopolitanism.

\section{Claims of Cosmopolitan Arrogance}

Yack has offered perhaps the most comprehensive such claims. He again argues that attempts by theorists to distance themselves from the "arrogance of earlier cosmopolitanisms," (2012, 285) render their accounts incoherent. This is the case both for 'rooted' cosmopolitans seeking to incorporate non-universal moral values, and for institutional cosmopolitans who advocate dispersing coercive and political power globally rather than centralizing it in "an 
older and more arrogant vision of cosmopolitan political organization, with its frightening images of a world state and a world sovereign" $(2012,284)$.

The problem in both cases, he argues, is that cosmopolitans have adopted approaches incapable of addressing the 'morally problematic' aspects of nationalism. In other words, it is fundamental to a cosmopolitan view that national loyalties must be subsumed within larger ones to all humanity, and thus that sovereign nation-states must be subsumed within a larger political entity exercising state-like coercion and political supremacy. Yack himself offers a non-cosmopolitan view of national loyalty which affirms it as a form of 'social friendship,' under which "our sense of community disposes us to express some degree of concern for the well-being of large numbers of people toward whose fate we would otherwise be indifferent or hostile" $(2012,169)$. He contrasts this, however, with nationalism and the pursuit of sovereign self-determination for national communities. Nationalism marries the good of social friendship to an impersonal sense of justice which can easily turn to a sense of grievance, stemming from "a belief that outsiders are obliged to allow us, as members of a nation, to organize our own political lives. From this perspective, those who impede our nation's efforts to gain control of its political affairs strike us as wrongdoers ... As such, they are deemed to merit punishment as well as resistance" (Yack 2012, 215).

For Yack, this is the moral problem with nationalism. When nations are presumed to be the appropriate locus of ultimate political authority, as in the current system of nationstates, they tend toward promoting enmity and violence against non-nationals (Yack 2012, Ch.9). Cosmopolitanism may seem like the natural place to turn for a solution, he says, but cosmopolitans again face a dilemma. They can be 'humble,' adopting rooted cosmopolitanism and rejecting global political integration, while failing to address the problems which arise from nationalism. Or, they can seek to impose fully global political structures and moral principles, while arrogantly disdaining particularist, non-global moral 
views. For Yack, only the latter is theoretically consistent with cosmopolitanism $(2012,254-$ 55), but it should be rejected. Instead, he advocates working to moderate nationalism's negative effects, while at the same time affirming the moral importance of national loyalty as a form of social friendship which most people see as valuable in their lives (2012, 286ff).

Yack and others again offer two overarching arrogance objections against cosmopolitanism. The first is that non-universal moral claims are treated as not authorized within a cosmopolitan approach. The second charges moral parochialism: cosmopolitanism only masquerades as a neutral universal moral doctrine. It seeks to disguise its Western- or Euro-centric roots and their highly problematic presumptions of hierarchy among the world's peoples, but these presumptions remain implicit in it (Pinsky 1996; Malcomson 1998; Pagden 2000; Audard 2013; Jeffers 2013; Helliwell and Hindess 2015). Thus, the cosmopolitan wrongly rejects especially those within non-Western cultures as not qualified to make moral claims. Overall, Yack asserts, for theoretically consistent, arrogant cosmopolitans, "Disdaining partial attachments as sources of moral insight both narrows their understanding of humanity and blinds them to their own reliance on partial viewpoints and loyalties" (2012, $85)$.

\section{Institutional Cosmopolitanism and Global Citizenship}

I will work to show how an appropriately configured institutional cosmopolitanism helps to address both objections rather than reinforce them. Here I will present what I take to be a theoretically consistent such cosmopolitan approach. This is one which has a conception of global citizenship at its core and is committed to developing formalized practices of citizenship within regional and global cosmopolitan institutions over time. I will also show how the case for such an institutional cosmopolitanism, or 'institutional global citizenship,' is 
partly grounded in some significant political arrogance objections against the current system of sovereign states.

Institutional cosmopolitanism is again a variant which supports the development of relatively strongly empowered global institutions to back cosmopolitan aims. These are often construed as aims for global rights fulfillment (Pogge 1992; Caney 2005, Ch.5; Cabrera 2010, Ch. 2), and I will adopt that presumption here. Arguments for such an approach typically emphasize collective action, assurance and related problems which are endemic to a sovereign states system and pose barriers to the realization of rights aims. The development of democratic global political institutions is prescribed as a means of overcoming the barriers (Pogge 1992; Ypi 2013), and also of enabling participation on determining the goods that global institutions should seek to provide (Caney 2006; Lu 2018, 234-35). Related are arguments by some 'cosmopolitan democrats' (Held 1995; see Marchetti 2008). They advocate the development of binding democratic global institutions as a means of ensuring popular democratic control of policy making in an era where much decision making has been shifting upward, away from domestic polities.

I have argued elsewhere for a primarily instrumental approach to cosmopolitan institutions. It sees such institutions, and democratic participation, legal and other accountability mechanisms within them, as primarily instrumental to achieving aims for global rights fulfilment consistent with treating all persons' interests as equally weighty (Cabrera 2010, Ch.2). Such a system would be committed both to the protection of fundamental interests corresponding to rights - nutrition, shelter, health care, physical safety - and to enabling the global pursuit and specification over time of broader, more aspirational and egalitarian rights to education and training, 'more equal' opportunities in the form of freer movement across borders, and others. 
This approach would emphasize the instrumental importance of such institutions for addressing the collective action and assurance problems noted, and for addressing related biases against cosmopolitan distributive and other aims which naturally arise within a sovereign states system. These include electoral or stakeholder biases, where leaders have strong incentives to prioritize the preferences of their own constituents over even the most pressing needs of perceived outsiders. They also include the own-case bias familiar from social contract theory, where individuals and states tend to be biased in their own case, and where states are also typically the judges in their own cases. And they include a type of stewardship bias, where prerogatives of sovereignty are ascribed to states as stewards of their own populations' interests (see Cabrera 2010, 57-64). A truly 'cosmopolitan state' would subvert its stewardship role in the current system if it gave no particular priority to its own population's interests.

\section{Political Arrogance and Sovereign States}

Here I want to add a further concern related to the stewardship role of states. That is, the current system can be said to embody forms of both vertical and horizontal political arrogance, since it empowers states to reject the standing of some to offer input and challenges when it should not. We can note first that the UN Charter, which specifies the main principles of the system, gives emphasis to the stewardship roles of states in relation to individual rights, alongside an emphasis on political self-determination. The Charter's Preamble states in its second line that a core purpose of establishing the UN was "to reaffirm faith in fundamental human rights, in the dignity and worth of the human person, in the equal rights of men and women and of nations large and small..." (United Nations 1945). The Universal Declaration of Human Rights, and especially the binding UN human rights treaties which have followed it, give additional emphasis to the promotion and protection of such 
rights within the system. Thus, the UN's 193 member states are allocated equal stewardship responsibility for the promotion of universal human rights, and it is this role which does much to justify states' sovereign prerogatives to vertically oriented internal supremacy and horizontally oriented sovereign equality with other states (see Reus-Smit 2001). The importance of the rights stewardship role in justifying prerogatives of sovereignty has been reinforced in recent years, for example in the UN-backed doctrine of Responsibility to Protect. Under that doctrine, states are said to surrender their non-interference rights when they commit severe, large-scale rights violations internally (United Nations 2018).

In terms of vertically oriented political arrogance then, the claim is this: it is incoherent to grant states' leaders authority to summarily reject individuals' standing to challenge internal rights violations when that authority is grounded significantly in the state's assigned role as rights protector. The problem is acute when leaders assert their sovereign privileges to serve as ultimate judge against suprastate institutions charged with the oversight of the rights, as in the Universal Periodic Review process of the UN Human Rights Council. There, states are judged on their record of protecting important human rights over several years, concerns are raised, and corrective actions typically prescribed (see Milewicz and Goodin 2018). States need not act on the findings, however. They are empowered in the system to determine that such oversight bodies, and the domestic groups which often bring rights claims to the bodies, are not authorized to dictate changes. Such actors do not have standing to challenge the state's sovereign prerogative to be the ultimate judge in its own case. Thus, in cases of clear and significant violations, leaders would be broadly analogous to the umpire above: he has failed to perform the role of an umpire in making a clearly incorrect play call, but he claims sole authorization to make the call based on the ascribed role of the umpire - to make correct such calls. 
Some similar challenges hold horizontally, where states, or states' leaders, are equally assigned stewardship roles but have vastly different capacities to protect the specified human rights for their own populations (UN Development Programme 2016). The segregated, 'separate but equal' global system of stewardship thus often fails to ensure that the rights it specifies for all persons are actually protected and promoted for all. Yet, sovereign prerogatives which are affirmed by that system are based significantly in presumptions that it will effectively allocate the protection of core rights. Those prerogatives empower states again to summarily reject as not authorized any horizontally oriented claims from other states or individuals for more robust material distributions, for economic opportunities in the form of freer movement, and for the most vital protections of life and person in relation to asylum seekers. The 'umpire' in this case is the global system of stewardship allocation. It is that allocation of responsibility which grounds each states' sovereign authority to reject claims by outsiders, even as it results in ongoing, large-scale rights underfulfillment globally.

In both the vertical and horizontal cases, then, the logic of the system itself indicates the need for suprastate, cosmopolitan institutions which could enable input and challenges, and which could resolve disputes in ways which treat the fundamental interests of all persons as being of equal significance. These considerations, with the collective action problems and inherent biases noted above, should give some indication of the case for institutional cosmopolitanism. The next section discusses the role of global citizenship within an instrumentally oriented institutional cosmopolitan approach.

\section{Institutional Global Citizenship}

Global citizenship is understood here again as individual cosmopolitanism. It seeks to establish principles for action by individuals which would be consistent with cosmopolitan moral aims. Under a conception of institutional global citizenship, duties would in part be 
oriented to the development of more cosmopolitan regional and global institutions. Thus, global citizenship is seen in part as crucial to the development of such institutions. It also would be crucial to their actually promoting cosmopolitan aims for rights fulfillment, and for helping to orient them structurally to political humility rather than arrogance.

We can note first a longstanding objection, that the concept of global citizenship is incoherent in the absence of some world state (see Mason 2012, Ch. 8). The approach here aims in part to answer such an objection by emphasizing ways in which specific elements of citizenship can be extended. That is, individuals can act 'like' global citizens in some significant ways in the absence of integrated global political institutions, particularly in seeking to contribute to the fulfillment of core rights for those who do not share their state citizenship. Such global citizen action could include offering material and other forms of support across state borders. It could entail advocacy and support for refugees and economic migrants within their own borders, advocacy directed at their own state's relevant foreign policy actions, and advocacy efforts related to the development of more-cosmopolitan institutions regionally and globally.

Such suprastate institutions are indeed in developmental status, with often very limited governance capacities and participatory or accountability mechanisms. Some global institutions indicated by institutional cosmopolitanism do not yet exist. Yet, the 'institutionally developmental' duties of regional and global citizenship outlined here are not distinct in kind from domestic duties incumbent on citizens of impoverished, conflict-riven or otherwise fragile states. For example, the Fragile States Index assesses more than 100 of 178 states as falling into a serious 'warning' or 'alert' category for institutional and other forms of instability. This means - especially for the 30 countries in the alert category -- that they have limited ability to fully back citizen rights and ensure the discharge of duties (Fund for Peace 2018). In the case of such states, as with most regional and global institutions, a significant 
part of what it means to act 'like a citizen' will be to support the development of political institutions within which a more robust and concrete citizenship practice can be established over time.

A conception of global citizenship is integral to a scheme of institutional cosmopolitanism in both instrumental and non-instrumental ways. In terms of the latter, positing equal global citizen status for all persons will reflect the basic cosmopolitan commitment to affirming the equal worth and ultimate moral significance of all persons. Such a claim is similar to that offered by some theorists of domestic democracy and citizenship, who see equal democratic citizenship as reflecting moral equality among persons (Christiano 2008; Mason 2012). In political humility terms, it would constitute a recognition of the formally equal standing of all persons to offer input and lodge challenges.

More instrumentally, realizing progress toward creating global cosmopolitan political institutions in the longer term would depend significantly on the outward development of the elements of global citizenship. It would depend on individuals being able to view themselves as members of broader communities, being willing to participate in the development of more robust political institutions at the regional and ultimately global level, and to support or contest laws and polices proposed within them. It would depend on their ultimate willingness to acknowledge the equal standing and rights claims of others, and to acknowledge broader sets of duties. This is not to make any prediction that most persons will necessarily expand their own views of citizenship. It is rather a claim that the development of genuinely cosmopolitan political institutions also will depend on the enactment of aspects of global citizenship in the near term, and movement in the longer term toward the acceptance by individuals of global citizenship status and the rights and duties it entails.

Global citizenship would be similarly integral to furthering and sustaining the rightsprotective, cosmopolitan character of suprastate political institutions as they develop. This 
claim is consonant with instrumental justifications of democratic rule more generally. In such accounts, democracy is seen as justified primarily by the moral goods it helps to promote, in

particular individual rights protections, but also social justice more broadly construed; as well as epistemic goods relating to the quality of decision making. Political and related civil rights are valued for the roles they can play in promoting protections of rights against bodily harm, to economic and social welfare rights, and a range of others (see Sen 1999, Ch.6; Talbott 2005, Ch. 7; Christiano 2011; Van Parijs 2011, Ch.1) In the institutional cosmopolitanism context, 'global civil rights' would be vital tools for use in ensuring that the suprastate institutions helped advance cosmopolitan moral aims for promoting economic, social and other rights protections. They also would be crucial to challenging forms of vertical and horizontal political arrogance, per above.

The following section examines in more detail the specific arrogance charges against cosmopolitanism. In each case, I will work to show, a conception of institutional cosmopolitanism which appropriately places global citizenship at its core can help to answer rather than reinforce the objections.

\section{Arrogance 1: Particularist Moral Claims}

The first arrogance claim again is that a theoretically consistent cosmopolitanism will reject moral significance for particular attachments, and thus will reject the standing of those in particularist relationships to make moral claims from them. It is arrogant because it wrongly rejects such moral claims as not authorized. As Yack says of would-be rooted or moderate cosmopolitans, who again seek to incorporate some particularist views within a universalist moral framework, "The difficult point for these cosmopolitans is to explain why these universal standards should take precedence over those generated by more local and partial communities, and to do so without falling back into the kind of disdain for ordinary 
communal life that they were trying to escape in the first place" $(2012,259-60)$. For Yack, they cannot. A theoretically consistent cosmopolitanism will reject such claims. In so doing, it will fail to show adequate respect to particularist claims makers; it evinces disdain for their views and is arrogant toward them.

First, why should we presume that a theoretically consistent cosmopolitanism must disdain particular attachments, even interpersonal ones, and particularist moral claims made from them? We can turn here to some detailed critiques Martha Nussbaum has offered of cosmopolitanism's treatment of such attachments. In earlier work, Nussbaum championed moral cosmopolitanism and held up classical Greek and Roman Stoic thinkers as having achieved an appropriate relationship between a universalistic morality and more local belongings and attachments. The Stoics, she said, indicated a useful, concentric-circles model in which special duties were allocated to family and community as a means of ensuring the effective discharge of global duties $(1997,59-63)$. Thus, non-universal special duties were to be viewed as instrumental to fulfilling universal cosmopolitan ones.

More recently, Nussbaum has rejected Stoic cosmopolitanism, and a cosmopolitan moral view in general, as inappropriately dismissing the importance of interpersonal attachments to human lives:

I do not, however, even endorse cosmopolitanism as a correct comprehensive doctrine. Further thought about Stoic cosmopolitanism, and particularly the strict form of it developed by Marcus Aurelius, persuaded me that the denial of particular attachments leaves life empty of meaning for most of us ... The dark side of Stoic thought is the conviction that life contains merely a sequence of meaningless episodes, once particular attachments have been uprooted (Nussbaum 2008, 80; see Nussbaum 2003).

Further, she reverses her earlier view of special duties as simply instrumental to achieving cosmopolitan ones. Instead, she emphasizes the importance of acknowledging "particularistic forms of love and attachment, pursued for their own sake and not just as derivative from universal duties to humanity" $(2008,80)$. Determining our own duties to others, she holds, 
should be approached as "an uneven dialectical oscillation within ourselves, as we accept the constraints of some strong duties to humanity, and then ask ourselves how far we are entitled to devote ourselves to the particular people and places whom we love" (Nussbaum 2008, 80).

Yack argues for a somewhat more expansive emphasis on particularist social friendship or national loyalty in determining duties to others, "as a way of protecting ourselves from the harm caused by excessive confidence in our ability to discern what people deserve from each other," strictly in terms of impersonal principles of justice $(2012,179)$. Yet, he gives little guidance as to how tensions between moral claims stemming from social friendship and those of justice are to be balanced. He asserts that a disposition to social friendship "reaches its limit when it leads us to violate some fundamental obligation that we believe we owe to others or to hurt other groups with whom we also share feelings of mutual concern." He cites racism as an example of where current limits are set $(2012,166)$.

Thus, we can note that both Yack and Nussbaum offer primarily subjectivist approaches to determining duties. 'We' as individuals or communal collectives are to set the limit when we have determined that some form of partiality has become unacceptable. Nussbaum continues to argue that all states should work to secure a set of universal capabilities for all in their populations - broadly similar to securing basic human rights. She rejects the development of strongly empowered suprastate institutions to back such commitments, however, saying that "we ought to respect the state, that is, the institutions of the basic structure of society that a given group of people have accepted and that are accountable to them. The state is seen as morally important because it is an expression of human choice and autonomy" (Nussbaum 2006, 261-62). More affluent states are to be exhorted to aid others, but they individually set limits on their own duties.

Such subjectivist approaches to setting limits on duties to others are, I will suggest, aligned with both horizontal and vertical forms of political arrogance. Horizontally, neither 
input nor challenges - on international distributive duties, migration and asylum regimes, contributions to climate change, etc. -- would necessarily be permitted from those outside the deciding 'we.' Nussbaum does advocate the creation of some problem-oriented suprastate institutions, but their capacities would be significantly limited by the emphasis on collective domestic choice. Vertically, individuals within sub-groups, and sub-groups themselves within states, could have very limited means of offering their own challenges, including against culturally-backed repression.

How, then, can cosmopolitanism coherently establish globally oriented limits on special duties while avoiding forms of political arrogance in relation to particularist groups and non-universalist moral views? It can do so in part through adopting an institutional global citizenship approach. This would seek to set limits consistent with an acknowledgment of the equal moral standing of all persons, but also to establish the equal concrete standing of all persons to offer input and challenges on limits, including many based in particular attachments and views. I will begin by addressing the claim that a theoretically consistent cosmopolitanism demands that any special duties presumed to family, friends or compatriots must be shown to be instrumental to advancing universal cosmopolitan duties (Nussbaum 1997, 61; see Scheffler 1999, 263). Claims for non-cosmopolitan special duties thus would not be authorized.

First, I will note nothing in cosmopolitanism per se demands the adoption of a 'very extreme' version which would stipulate such first-order impartialism, ${ }^{3}$ any more than a nation- or state-centric approach must demand that all duties discharged to others advance

\footnotetext{
${ }^{3}$ Peter Singer offered such a stringently impartialist view in the initial presentation of his act-utilitarian approach to addressing global poverty. He argued that the relatively affluent globally were obligated to give to the point where they made themselves as badly off as those in dire need (1972). Singer has more recently argued that if that very demanding principle would create a counter-productive backlash, a far less demanding one would be appropriate (2009). The salient point here would be that the egalitarian commitments of cosmopolitanism plausibly could be realized by a range of other principles, and the approach itself is not bound to a stringent consequentialism.
} 
fully national aims. Rather, it would require that exclusions or unequal treatment for any persons be justified in a way that is consistent with recognizing their equal moral worth (Weinstock 2012, 89; see Knight 2011, 23). Special duties to others may thus be assumed for a variety of reasons, but within limits set by cosmopolitan commitments. Structurally, this will be similar to ways in which domestic schemes limit special duties even to close family members, by reference to broader concerns of fairness, etc., to co-equal citizens. Such limitations commonly include rules on nepotism in public employment, redistributive inheritance taxes which limit family priority and promote more egalitarian social opportunities, legal bars on wrongdoing to benefit family members. Similarly, cosmopolitan institutions would give precedence to considerations of fairness for all persons, rather than solely to other compatriots.

Moral claims still could be made in either system according to the importance of some interpersonal attachments. In fact, in a more cosmopolitan system, claims for special duties to family members actually could be farther reaching. This is because they could be lodged in suprastate venues, including horizontally, by persons from one state seeking to challenge exclusions and/or harsh treatment by those in another state. Consider the U.S. context, where the Trump administration in 2018 began routinely separating children from parents when apprehending unauthorized migrants at the U.S. Mexico border, as a means of deterring attempts by others. One high-ranking U.S. official maintained that the children's welfare would not be harmed by the policy (NPR 2018). Even if it were somehow the case that their overall material welfare would be enhanced, however, there would still be strong reason to enable legal challenges to such a policy, based in the non-instrumental importance of most parent-child attachments. An institutional global citizenship approach would seek to facilitate such challenges. It would aim to create or strengthen suprastate courts within which they could be lodged when such challenges are rejected as not authorized by states, and in which 
possible forms of horizontal political arrogance could be highlighted and contested more broadly. ${ }^{4}$ Individuals could thus see enhanced opportunities within a more-cosmopolitan institutional system to make claims based in the moral importance of interpersonal attachments, alongside more impersonal justice-based claims.

What then of appeals based in broader particular attachments, to culture or nation? We can note first that an institutional global citizenship approach would also be more farreaching than the current system in seeking to enable some formal challenges based in cultural claims. These could involve, for example, groups' competing claims to a religious or cultural site such as Jerusalem. A consistent institutional cosmopolitanism would seek to establish venues within which such claims could be heard before a neutral arbiter whose judgments would have binding force.

It would not, however, support general and categorical claims for priority to conationals or state compatriots. This is in part from a distinction made by Arneson and others, between the importance of positive interpersonal attachments which directly contribute to one's well-being, and "anonymous ties among members of large groups [which] lack these special features" $(2016,558)$. Arneson would limit special duties to compatriots, and moral claims from them, accordingly. He and others have also raised important concerns for statist, nationalist or otherwise associative accounts which would seek to establish a categorical priority to compatriots based in existing relations of reciprocity, coercion, etc., among them (Arneson 2016, 566-70; see Caney 2008; Brock 2009, Ch. 10; Cabrera 2010, Ch. 2). One such concern is the horizontal political arrogance noted for Nussbaum and Yack's duties claims above. Associativist accounts argue for a framework in which the compatriot or conational 'we' has near-categorical rights to reject the standing of outsiders to lodge actionable

\footnotetext{
${ }^{4}$ See Føllesdal 2016 on the operation of such regional courts as the European Court of Human Rights and InterAmerican Court of Human Rights; see also Mayerfeld 2016; for a more critical view, see Bellamy 2008.
} 
challenges. Yet, they have difficulty justifying the initial setting of boundaries which are said to generate the morally significant relations among the 'we,' and to ground the ongoing exclusion of outsiders, among other problems. ${ }^{5}$

There are, however, some other kinds of particularist claims which could be expected to arise within an institutional cosmopolitanism framework, just as they do in constitutional democracies. These would involve individuals' claims to exemptions from laws or rules based in religious beliefs, indigenous groups' claims to the use of ancestral lands or resources, among many others (see Kelly, ed., 2002). In such cases, fairness to all persons as citizen equals must be balanced against particular claims, though many of the latter are based in historical injustices, raising additional issues. These are typically hard cases and would be no easier for an institutional global citizenship scheme. Again, however, it would seek to check possibilities for political arrogance against such groups and ensure that their claims could be heard if necessary in a neutral suprastate court or ombuds forum.

Importantly, cosmopolitan commitments would mean that individuals must also be able to bring claims against possibly repressive practices in their own communal groups, including at the suprastate level if necessary. For example, if the group is dominant within a state, it may be necessary for those experiencing oppression within it to reach beyond the state, to lodge vertically oriented challenges. We can note ongoing such efforts by Dalit (formerly 'untouchable') activists in India. Over the past two decades, they have sought to enlist United Nations human rights bodies in pressing the Indian government to do more against continuing caste discrimination. Highly salient here, they have faced ongoing resistance and critique from Indian government leaders, who argue effectively that the activists are not authorized to take their claims beyond the state, and explicitly that UN bodies have no authorization to dictate domestic action on the activists' claims (see Cabrera

\footnotetext{
${ }^{5}$ I critically examine recent associative accounts in more detail in Cabrera forthcoming, Ch.6.
} 
2017; forthcoming, Ch.5). An institutional global citizenship would be committed to giving such groups more formalized and powerful mechanisms of challenge beyond the state.

Finally, we can note a point well made by Simon Caney, that many particularist claims themselves imply a cosmopolitan approach. He observes that inherent in claims for the importance of respecting cultural diversity and particular attachments is that individuals are presumed to have affirmed cultural norms for themselves. This, he argues, provides a powerful reason to support distributions to less-affluent persons globally: "we can see that respecting a cultural practice makes sense only if its members truly affirm it and that this requires that the members have both the material resources to leave and the material resources to affect the formation of social norms" (Caney 2000, 544). ${ }^{6}$

\section{Arrogance 2: Cosmopolitan Moral Parochialism}

It could be argued, however, that cosmopolitanism still arrogantly rejects particularist views, in demanding that claims from them be made within a universalist egalitarian framework -one which is itself morally parochial in reflecting Western- or Euro-centric views. Robert Pinsky makes the point forcefully, explicitly charging arrogance. In a response to the earlier Nussbaum, he warns against "the arrogance that would correct your provinciality with the cosmopolitanism of my terms. The Muslim or Marxist or Rastafarian might draw Nussbaum's same Stoic diagram of concentric circles, but the labels would build toward a different, less cozy idea of the universal" (Pinsky 1996, 88). More generally, an egalitarian cosmopolitan doctrine could seem foreign to many asked to accept it. For critics such as Pagden (2000) and Jeffers (2013), the core problem with an approach which has its roots in

\footnotetext{
${ }^{6}$ Caney also notes here that concerns about domestic cultural imposition give reason to support cosmopolitan suprastate institutions. His proposed institutional scheme (Caney 2006) would justify global democracy as a means of settling 'reasonable disagreement' among persons, rather than primarily for its instrumental contributions to enabling protection of rights. Thus, his treatment does not give emphasis to legal or other challenge mechanisms for individuals operating alongside majoritarian democratic procedures. I discuss Caney's approach to global democracy at length elsewhere (Cabrera forthcoming, Ch.7).
} 
Enlightenment European liberalism is that it will reflect the problematically hierarchical view of the world's peoples held by Kant and other early liberals. Implicitly, it continues to treat those adhering to non-Western, non-liberal views as subordinate and not qualified to make claims (see also Malcomson 1998, 238; Audard 2013; Helliwell and Hindess 2015).

This is a potentially significant critique, and one that has been made more generally against doctrines of universal human rights. In that context, we can note first a response from Allen Buchanan, highlighting ways in which the international human rights regime has expanded input over time on rights interpretations and the creation of new rights conventions. He notes that "a system of legal rights that is created and developed through the participation of people from many cultures should be less prone to parochialism in its understanding of those rights..." (Buchanan 2013, 115-16). In the distinctive context of institutional global citizenship, the commitment to formally equal standing would be aimed at further expanding such input, and enabling more extensive and formalized challenges, including those which would make objectionable parochialism more visible.

We can acknowledge that such challenges would indeed be lodged in an explicitly egalitarian framework, committed to establishing concrete political equality. It would thus strongly resist particularist views which reject equal standing for persons because of their gender, ethnicity, caste, religion, nationality, etc. It would also challenge views that non-elites are generally not qualified to participate in their own governance. Both stances are consistent with more general arguments for democratic political equality. Highly salient here are arguments from Indian Constitutional architect and anti-caste campaigner B.R. Ambedkar (1891-1956), whose thought and actions have deeply influenced the globally oriented Dalit activists noted above. Ambedkar offered a range of sophisticated arguments against dominant cultural and religious mores which affirmed subordination for Dalits and other groups in the Hindu caste system (Ambedkar 2014[1936]). He championed political equality under a 
democratic constitution which explicitly barred practices of untouchability and specified equal civil and participatory rights for all citizens, as well as reservations in elections, public employment and education for Dalits and tribal groups.

Further, from the 1930s, Ambedkar indicated support for a multi-level global model in which vulnerable domestic minorities could lodge formal vertical challenges against forms of repression and political arrogance. He later corresponded on the model with W.E.B. Du Bois, who led African-American groups in outreach to the United Nations against racial discrimination in the 1940s (see Cabrera 2017, 286-88; forthcoming, Ch.6). The present-day Dalit activists have followed a similar script. An institutional global citizenship approach seeks to more broadly empower such groups in making these kinds of suprastate challenges. It would also seek to empower those in post-colonial societies, and in historically disadvantaged groups or societies, to more effectively challenge problematic presumptions of hierarchy which influence states' policy actions and attitudes on, for example, migration from certain regions. As a cosmopolitan approach, it would be universalist and would share some emphases with Kant and others whose thought has informed that tradition. Yet, it also would also enable challenges to views, policies and actions reflecting the hierarchical or extremeimpartialist 'dark sides' (Nussbaum 2008, 80) of the tradition, even as it strives to expand mechanisms of challenge more generally against political arrogance and injustice.

\section{Institutional Cosmopolitanism and Intellectual Arrogance}

Finally, we can consider Yack's claim that cosmopolitans must support the development of some very powerful global political institutions (see also Scheuerman 2014). I will suggest here that such an analysis evinces an intellectual arrogance which a consistent institutional cosmopolitanism can avoid. Yack presumes that it would need effectively a powerful security world state to control nationalism in a way consistent with cosmopolitanism principles. Such 
a 'cure,' however, could well be worse than the disease. It would not be coherent for the cosmopolitan to reject all standing for non-global communities and prescribe some massive global concentration of power which could severely threaten the very rights or other moral aims to be promoted.

More consistent would be an instrumentally oriented approach seeking distributions of political authority and coercive capacity which could be effective for promoting individual rights for all persons, while observing constraints on rights promotion set by respect for the same rights. This could entail, for example, progressive economic and political integration between states within more-cosmopolitan suprastate institutions. Such integration could make more possible over time the scaling down of states' offensive military forces. If that could be achieved, then some distributed scheme of state, regional and global peacekeeping and policing forces could be pursued, within a system where global-level institutions would exercise political supremacy on a significant range of policy issues. Such a distribution could strike the appropriate balance between capacity to ensure that core rights are protected and that threats to those rights from state and suprastate security powers are held in check.

Whether such developments would ultimately prove feasible, the key point here is that there is nothing inherent to institutional cosmopolitanism, in particular the instrumentally oriented institutional global citizenship approach, which would dictate a massive concentration of global coercive power aligned with "frightening images of a world state and a world sovereign" (Yack 2012, 284). Nor would it necessarily prescribe the summary 'imposition' of some specific institutional or democratic-procedural form over the entire world, even were such imposition conceivable in the near term. It would, however, seek to progressively establish concrete equal standing among persons, promote democratic input and exchange among them, and provide mechanisms for challenging vertical and horizontal 
political arrogance at all institutional levels. It would thus be fundamentally oriented to political humility.

\section{Conclusion}

This article has sought to answer claims that cosmopolitanism is inherently arrogant, and that an institutional cosmopolitanism, seeking to develop global political institutions to back global moral claims, intensifies the problem. After detailing some primary variants of cosmopolitanism, it presented both arrogance and humility as focused on standing. Humility entails acknowledging the equal standing of others to give input and raise challenges; arrogance rejects input, typically on grounds that those giving it are not qualified or not authorized to do so. Political humility and arrogance were shown to entail a collective, structural orientation to openness or rejection.

The general case for institutional cosmopolitanism was then presented, and some reasons were offered to think that the current system of sovereign states aligns with political arrogance as wrongful rejection of standing in key ways. Specifically, states are empowered to summarily reject the standing of individuals or groups to offer challenges concerning the very rights protective-roles which significantly ground state powers to reject. Global citizenship was then shown to be integral to institutional cosmopolitanism, including for challenging such forms of political arrogance. Two common arrogance critiques of cosmopolitanism were engaged. These charge that cosmopolitanism wrongly rejects claims made from non-universal views as not authorized; and that it is morally parochial, rejecting the standing of persons adhering to non-Western, non-liberal views implicitly on grounds that they are not qualified. An emphasis on institutional global citizenship was shown to help answer both kinds of objections. 
Overall, the discussion has highlighted some important ways in which an appropriately configured cosmopolitanism, instead of reinforcing objectionable forms of exclusion, would seek to multiply opportunities for input and challenge both vertically and horizontally: between states' populations and their leaders, and between individuals globally. In so doing, it is structurally oriented to political humility, and its development would be instrumental for contesting forms of political arrogance, injustice and inequality inherent to the current global system.

\section{Works Cited}

Aikin, S.F., \& Clanton, C. (2010). Developing group-deliberative virtues. Journal of Applied Philosophy, 27(4), 409-24.

Ambedkar, B.R. (2014[1936]). Annihilation of caste, S. Anand (Ed.). New Delhi: Navayana. Appiah, K.A. (2006). Cosmopolitanism: ethics in a world of strangers. London: Penguin.

Arneson, R.J. (2016). Extreme cosmopolitanisms defended. Critical Review of International Social and Political Philosophy, 19(5), 555-73.

Ashton, M.C., and Lee, K. (2008). The hexaco model of personality structure and the importance of the h factor. Social and Personality Psychology Compass, 2(5), 1952-62.

Audard, C. (2006). Peace or justice? Some remarks on Rawls's law of peoples. Revue Internationale de Philosophie, 60(3), 301-26.

Beitz, C. (1999a). Political theory and international relations, Revised Edition. Princeton: Princeton University Press.

Beitz, C. (1999b). Social and cosmopolitan liberalism. International Affairs, 75(3), 515-29.

Bellamy, R. (2008). Evaluating union citizenship: belonging, rights and participation within the EU. Citizenship Studies, 12(6), 597-611.

Blake, M. (2013). Justice and foreign policy. Oxford: Oxford University Press.

Brock, G. (2009). Global justice: a cosmopolitan account. Oxford: Oxford University Press.

Buchanan, A. (2013). The heart of human rights. Oxford: Oxford University Press.

Button, M. (2005). A ‘monkish kind of virtue?' For and against humility. Political Theory, $33(6), 840-68$. 
Button, M. (2016). Political Vices. Oxford: Oxford University Press.

Cabrera, L. (2010). The practice of global citizenship. Cambridge: Cambridge University Press.

Cabrera, L. (2017). Dalit cosmopolitans: institutionally developmental global citizenship in struggles against caste discrimination. Review of International Studies, 43(2), 280-301.

Cabrera, L. (2018), Introduction: institutions as a cosmopolitan concern, in L. Cabrera (Ed.), Institutional cosmopolitanism (pp. 1-20). New York: Oxford University Press.

Cabrera, L. (forthcoming). The humble cosmopolitan: rights, diversity, and trans-state democracy. New York: Oxford University Press.

Caney, S. (2000). Cosmopolitan justice and cultural diversity. Global Society, 14(4), 525-51.

Caney, S. (2005). Justice beyond borders: a global political theory. Oxford: Oxford University Press.

Caney, S. (2006). Cosmopolitan justice and institutional design. Social Theory and Practice 32(4), 725-56.

Caney, S. (2008). Global distributive justice and the state. Political Studies, 56(3), 487-518.

Chancellor, J. \& Lyubomirsky, S. (2013). Humble beginnings: current trends, state perspectives, and hallmarks of humility. Social and Personality Psychology Compass, 7(11), 819-33.

Christiano, T. (2008). The constitution of equality: democratic authority and its limits. New York: Oxford University Press.

Christiano, T. (2011). An instrumental argument for a human right to democracy. Philosophy \& Public Affairs, 39(2), 142-76.

Davis, D.E., Worthington, E.L. Jr., \& Hook, J.N. (2010). Humility: review of measurement strategies and conceptualization as personality judgment. The Journal of Positive Psychology, $5(4), 243-52$.

Erskine, T. (2008). Embedded cosmopolitanism: duties to strangers and enemies in a world of 'dislocated communities.' Oxford: Oxford University Press.

Exline, J.J., \& Geyer, A.L. (2004). Perceptions of humility: a preliminary investigation. Self and Identity, 3(2), 95-114.

Føllesdal, A. (2016). Subsidiarity and international human-rights courts: respecting selfgovernance and protecting human rights — or neither? Law and Contemporary Problems, 79(2), 147-63.

Fund for Peace (2018). Fragile states index 2018. http://fundforpeace.org/fsi/ 
Retrieved June 22, 2018.

Gregg, A. \& and Mahadevan, N. (2014). Intellectual arrogance and intellectual humility: an evolutionary-epistemological account. Journal of Psychology and Theology, 42(1), 7-18.

Griffin, J. (2008). On human rights. Oxford: Oxford University Press.

Habermas, J. (2008). Between naturalism and religion. Cambridge: Polity.

Haggard, M., Rowatt, W.C., Leman, J.C., Meagher, B, Moore, C., Fergus, T., Whitcomb, D., Battaly, H., Baehr, J., Howard-Snyder, D. (2018). Finding middle ground between intellectual arrogance and intellectual servility: development and assessment of the limitations-owning intellectual humility scale. Personality and Individual Differences, 124(1), 184-93.

Held, D. (1995). Democracy and the global order: from the modern state to cosmopolitan governance. Cambridge: Polity Press.

Helliwell, C, \& Hindess, B (2015). Kantian cosmopolitanism and its limits. Critical Review of International Social and Political Philosophy, 18(1), 26-39.

Hurka, T. (2001). Virtue, vice, and value. New York: Oxford University Press.

Jeffers, C. (2013). Appiah's cosmopolitanism. The Southern Journal of Philosophy, 51(4), 488-510.

Jones, C. (2010). Human rights and moral cosmopolitanism. Critical Review of International Social and Political Philosophy, 13(1), 115-35.

Kamminga, M. (2006). Why global distributive justice cannot work. Acta Politica, 41(1), 21 40 .

Kelly, P. (Ed.), Multiculturalism reconsidered: Culture and Equality and its critics.

Cambridge: Polity, 2002.

Knight, C. (2011). In defence of cosmopolitanism. Theoria: A Journal of Social and Political Theory, 58(129), 19-34.

Kymlicka, W. \& Walker, K. (Eds.). (2012). Rooted cosmopolitanism: Canada and the world. Vancouver: University of British Columbia Press.

Lu, C. (2018). Cosmopolitan justice, democracy and the world state, in L. Cabrera (Ed.) Institutional cosmopolitanism (pp. 232-52). New York: Oxford University Press.

Malcomson, S.L. (1998). The varieties of cosmopolitan experience. In P. Cheah and B. Robbins (Eds.) Cosmopolitics: thinking and feeling beyond the nation. (pp. 233-45). Minneapolis: University of Minnesota Press.

Marchetti, R. (2008). Global democracy, for and against: ethical theory, institutional design, and social struggles. London: Routledge. 
Mason, A. (2012). Living together as equals: the demands of citizenship. Oxford: Oxford University Press.

Mayerfeld, J. (2016). The promise of human rights: constitutional government, democratic legitimacy and international law. Philadelphia: University of Pennsylvania Press.

Meagher, B.R., Leman, J.C., Bias, J.P., Latendresse, S.J., \& Rowatt, W.C. (2015). Contrasting self-report and consensus ratings of intellectual humility and arrogance. Journal of Research in Personality 58, 35-45.

Milewicz, K. \& Goodin, R. (2018). Deliberative capacity building through international organizations: the case of the universal periodic review of human rights. British Journal of Political Science, 48(2), 513-33.

Miller, D. (2002) Debate: Caney's 'international distributive justice': a response, Political Studies, 50(5), 974-77.

NPR (2018). Transcript: white house chief of staff John Kelly's interview with NPR. May 11, https://www.npr.org/2018/05/11/610116389/transcript-white-house-chief-of-staff-johnkellys-interview-with-npr Retrieved June 22, 2018.

Nussbaum, M. (1997). Cultivating humanity: a classical defense of reform in liberal education. Cambridge, MA: Harvard University Press.

Nussbaum, M. (2003). Compassion \& terror. Daedalus, 132(1), 10-26.

Nussbaum, M. (2006) Frontiers of justice: disability, nationality, species membership. Cambridge, MA: Belknap Harvard.

Nussbaum, M. (2008). Toward a globally sensitive patriotism. Daedalus, 137(3), 78-93.

Pagden, A. (2000). Stoicism, cosmopolitanism, and the legacies of European imperialism, Constellations, 7(1), 3-22.

Pinsky, R. (1996). Eros against esperanto, in J. Cohen (Ed.), For love of country: debating the limits of patriotism (pp. 85-90). Boston: Beacon Press.

Pogge, T. (1992). Cosmopolitanism and sovereignty. Ethics, 103(1), 48-75.

Reus-Smit, C., (2001). Human rights and the social construction of sovereignty. Review of International Studies, 27(4), 519-38.

Risse, M. (2012). On Global Justice. Princeton: Princeton University Press.

Roberts, R.C., and Wood, W.J. (2007). Intellectual Virtues: An Essay in Regulative Epistemology (Oxford: Clarendon Press). 
Ronzoni, M. (2013). For (some) political and institutional cosmopolitanism, (even if) against moral cosmopolitanism, in G. Brock (Ed.), Cosmopolitanism vs. non-cosmopolitanism: critiques, defenses, reconceptualizations (Oxford: Oxford University Press), 156-74.

Rowatt, W.C., et al. (2006). Development and initial validation of an implicit measure of humility relative to arrogance. The Journal of Positive Psychology, 1(4), 198-211.

Samuelson, P.L., Jarvinen, M., Paulus, T.B., Church, I.M., Hardy, S.A., \& Barrett, J.L. (2015). Implicit theories of intellectual virtues and vices: a focus on intellectual humility. The Journal of Positive Psychology, 10(5), 389-406.

Scheffler, S. (1999). Conceptions of cosmopolitanism. Utilitas, 11(3), 255-76

Scheuerman, W. (2014). Cosmopolitanism and the world state. Review of International Studies, 40(3), 419-41.

Scott, K. (2014). The political value of humility. Acta Politica, 49(2), 217-33.

Sen, A. (1999). Development as freedom. New York: Knopf.

Shapcott, R. (2010). International ethics: a critical introduction. Cambridge: Polity.

Singer, P. (1972). Famine, affluence and morality. Philosophy and Public Affairs, 1(3), 22943.

Singer, P. (2009). The life you can save: acting now to end world poverty. London: Picador.

Sinha, A.G. (2012). Modernizing the virtue of humility. Australasian Journal of Philosophy, 90(2), 259-74.

Spiegel, J.S. (2012). Open-mindedness and intellectual humility. Theory and Research in Education, 10(1), 27-38.

Tanesini, A. (2016). Calm down, dear: intellectual arrogance, silencing and ignorance, Aristotelian Society Supplementary Volume, 90(1), 71-92.

Tangney, J.P. (2005). Humility. In C.R. Snyder and S.J. Lopez (Eds.), Handbook of Positive Psychology (pp.411-19). New York: Oxford University Press.

Tiberius, V. \& Walker, J.D. (1998). Arrogance. American Philosophical Quarterly, 35(4), 379-90.

United Nations. (1945). Charter of the United Nations 1945:

http://www.un.org/en/sections/un-charter/un-charter-full-text/ Retrieved June 22, 2018.

United Nations Development Programme (2016). Human development report 2016: human development for everyone: http://www.hdr.undp.org/en/2016-report/download Retrieved June 22, 2016. 
United Nations Office of the Special Adviser on the Prevention of Genocide (2018). The responsibility to protect. http://www.un.org/en/genocideprevention/about-responsibility-toprotect.html Retrieved June 22, 2016.

Van Parijs, P. (2011). Just democracy: the Rawls-Machiavelli programme. Colchester: ECPR Press.

Weinstock, D. (2012). Rooted cosmopolitanism: unpacking the arguments. In W. Kymlicka and K. Walker (Eds.), Rooted cosmopolitanism: Canada and the world (pp. 87-104).

Vancouver: University of British Columbia Press.

Yack, B. (1995). Cosmopolitan humility. Boston Review, February-March.

http://bostonreview.net/archives/BR20.1/yack.html Retrieved June 22, 2018.

Yack, B. (2012). Nationalism and the moral psychology of community. Chicago: University of Chicago Press.

Ypi, L. (2013). Cosmopolitanism without if and without but. In G. Brock (Ed.), Cosmopolitanism versus non-cosmopolitanism: critiques, defences, reconceptualizations (pp. 75-91). Oxford: Oxford University Press. 